\title{
Evaluation of susceptibility of selected park rose cultivars to pests
}

\section{Ocena podatności wybranych odmian róż parkowych na szkodniki}

\author{
Ewa Sady*, Marta Matuszczak, Hanna Legutowska
}

\section{Summary}

The research was conducted at the Polish Akademii of Science Botanical Garden in Powsin on five cultivars of park roses (Frühlingsduft, Nevada, Marguerite Hilling, Poppius, Harison's Yellow) and one wild form (Rosa moyesii). The aim of this study was to evaluate the number of the most important pests such as spider mites (Tetranichidae), aphids (Aphidoidea) and rose leafhopper (Edwardsiana rosae L.) on rose leaves and to select the cultivar which is the most resistant to these pests. The observations were conducted in 2012-2013. Ten leaves were collected both from the upper and lower part of the shoot. In the laboratory conditions the pests were counted and symptoms of their feeding were observed. The largest number of pests, especially mites, was found on the cultivar Frühlingsduft rose. There were clear preferences in relation to cultivars in case of European red mite (Panonychus ulmi Koch), which showed in greater number only on the cultivar Frühlingsduft and in 2013 also Nevada, despite the possibility to move to other bushes. The least number of pests was generally observed on the cultivar Poppius.

Key words: park roses; rose pests; Tetranychus urticae; Panonychus ulmi; Macrosiphum rosae; Edwardsiana rosae

\section{Streszczenie}

Badania prowadzono w Ogrodzie Botanicznym Polskiej Akademii Nauk w Powsinie, na pięciu odmianach róż parkowych (Frühlingsduft, Nevada, Marguerite Hilling, Poppius, Harison's Yellow) oraz jednej formie dziko rosnącej (Rosa moyesii). Celem badań było określenie liczebności najważniejszych szkodników: przędziorków (Tetranychidae), mszyc (Aphidoidea) i skoczka różanego (Edwardsiana rosae L.) na liściach róż oraz wybór odmiany najbardziej odpornej na wymienione fitofagi. Obserwacje prowadzono w latach 2012-2013. Do badań pobierano po 10 liści złożonych z górnej i dolnej części pędów z poszczególnych odmian. W laboratorium liczono szkodniki i obserwowano objawy ich żerowania. Największą liczebność szkodników, przede wszystkim przędziorków, stwierdzono na odmianie Frühlingsduft. Wyraźne preferencje w stosunku do tej odmiany wykazywał przędziorek owocowiec (Panonychus ulmi Koch), który w większej liczbie pojawił się tylko na odmianie Frühlingsduft, a w 2013 roku również na odmianie Nevada, pomimo możliwości przemieszczania się szkodnika na inne odmiany. Najmniejszą ogólną liczbę fitofagów obserwowano na odmianie Poppius.

Słowa kluczowe: róże parkowe; szkodniki róż; Tetranychus urticae; Panonychus ulmi; Macrosiphum rosae; Edwardsiana rosae

\footnotetext{
Szkoła Główna Gospodarstwa Wiejskiego w Warszawie

Wydział Ogrodnictwa, Biotechnologii i Architektury Krajobrazu

Katedra Entomologii Stosowanej

Nowoursynowska 159, 02-776 Warszawa

*corresponding author: ewa.anna.sady@gmail.com
} 


\section{Wstęp / Introduction}

Róże są krzewami ozdobnymi bardzo często uprawianymi w ogrodach, nasadzeniach miejskich i parkach. Szczególnie istotną grupę stanowią róże parkowe, które cechują się zazwyczaj zwiększoną odpornością na choroby i szkodniki. Podatność poszczególnych odmian tej grupy na szkodniki nie została dokładnie przebadana. Do najważniejszych szkodników róż należą: przędziorek chmielowiec (Tetranychus urticae Koch), przędziorek owocowiec (Panonychus ulmi Koch), skoczek różany (Edwardsiana rosae L.) oraz mszycowate (Aphididae). Uszkodzenia powodowane przez te szkodniki sprawiają, że obniżane są walory dekoracyjne tych krzewów. Przędziorki nakłuwają tkankę liści, pąków kwiatowych i kwiatów, co skutkuje odbarwianiem kwiatów, żółtymi plamami na liściach, a w efekcie ich zasychaniem (McCaffery i wsp. 1989). Najmniej pożądanym objawem żerowania szkodnika z punktu widzenia producentów jest przedwczesne otwieranie się kwiatu, przez to płatki tracą swoją barwę (Dhooria 1999; Kumar i Nandihalli 2009). Przędziorek chmielowiec wytwarza również przędzę, która szpeci rośliny. Najczęściej spotykanym szkodnikiem z rodziny Aphididae na różach jest mszyca różana (Macrosiphum rosae L.), lecz mogą występować także inne gatunki: Chaetosiphon tetrarhodum (Walk.), mszyca różano-rutewkowa (Longicaudus trirhodus Walk.), mszyca różanotrawowa (Metopolophium dirhodum Walk.), Myzaphis rosarum (Kalt.) (Lubiarz i Solski 2012), Maculolachnus submacula (Walk.), mszyca burakowa (Aphis fabae Scop.) oraz mszyca smugowa (Macrosiphum euphorbiae Thom.) (Kmieć 2007). Owady te uszkadzają rośliny wysysając sok z liści oraz pąków kwiatowych, a ponadto są wektorami wielu groźnych wirusów (Chakrabarti 2005). Skutkiem ich żerowania są deformacje liści oraz pojawianie się rosy miodowej. $M$. rosae żeruje głównie na młodych liściach i pąkach kwiatowych. U tego gatunku obserwuje się partenogenezę cykliczną (Maelzer 1977). M. rosae występuje w dwóch formach barwnych - zielonej i różowej (Tomiuk i Wöhrmann 1984). Mszyce spotykane są zazwyczaj w wierzchołkowej części krzewów oraz na pąkach kwiatowych. Podobnie przędziorki obserwowane są w górnej części krzewu. Nie sprawdzano jednak rozmieszczenia tych szkodników w obrębie pędu, a jedynie na liściach (Budha i Thapa 2008).

Objawami żerowania kolejnego, ważnego szkodnika róż jakim jest skoczek różany, są drobne, żółte plamy na blaszce liściowej, które mogą pokrywać znaczną jej powierzchnię (Davoodi 1980).

Ważnym czynnikiem ograniczającym występowanie szkodników, szczególnie w miejscach nieobjętych ochroną chemiczną, są wrogowie naturalni. Liczebność mszyc ograniczają między innymi: pasożytnicze błonkówki (Jaśkiewicz i Sławińska 2005), drapieżne larwy z rodziny biedronkowatych (Coccinellidae) (Ferran i wsp. 1996; Lubiarz i Solski 2012), larwy złotooków (Chrysopidae) (Wnuk 2004, 2005; Jankowska 2005), a także larwy muchówek z rodziny bzygowatych (Syrphidae) (Markkula i wsp. 1979).

Celem badań była ocena zasiedlenia przez szkodniki liści wybranych odmian róż dobieranych do nasadzeń miejskich, parkowych i ogrodów przydomowych oraz wytypowanie odmian najmniej atrakcyjnych dla tych fitofagów, które można będzie zalecać do sadzenia w różnych typach ogrodów oraz w parkach.

\section{Materiały i metody / Materials and methods}

Badania przeprowadzano w latach 2012-2013 na terenie Ogrodu Botanicznego Polskiej Akademii Nauk w Powsinie. Do doświadczenia wytypowano pięć odmian róż: Frühlingsduft, Nevada, Harison's Yellow, Poppius, Marguerite Hilling oraz formę dziką Rosa moyesii (Hemsl. \& E.M. Wilson). Odmiana Frühlingsduft powstała w wyniku krzyżówki R. spinosissima z mieszańcem Joanna Hill. Ma pokrój wzniesiony, o przewieszających się pędach. Rośnie silnie, osiąga wysokość od 3 do 4 metrów. Kwiaty mają barwę od kremowej do bladoróżowej. Kwitnie od połowy maja przez cały sezon wegetacyjny. Nevada jest odmianą parkową powstałą ze skrzyżowania $R$. moyesii z mieszańcem herbatnim La Giralda. Osiagga wysokość do $3 \mathrm{~m}$, ma nieregularny pokrój. Kwiaty są białe, pojedyncze o średnicy około $10 \mathrm{~cm}$. Kwitnie od początku maja, powtarzając kwitnienie. Harison's Yellow pochodzi ze skrzyżowania $R$. spinosissima z $R$. foetida. Jest to krzew o pokroju wzniesionym i przewieszających się pędach. Dorasta do wysokości 1-2,5 metrów. Kwitnie na żółto od maja, nie powtarzając kwitnienia. Poppius jest krzyżówką $R$. spinosissima i $R$. pendulina. Jest to krzew gęsty, o wysokości 2-2,5 m. Kwitnie pod koniec maja, nie powtarzając kwitnienia, ma niewielkie, różowe, półpełne kwiaty. Marguerite Hilling pochodzi od odmiany Nevada. Charakteryzuje się wzniesionym pokrojem, dorasta do 2-2,5 m. Kwitnie na różowo, od czerwca przez cały sezon wegetacyjny. $R$. moyesii to forma dzika pochodząca z Chin, występująca w północnej i zachodniej części Polski. Krzew dorasta do wysokości 2 m, ma pokrój wzniesiony, przewieszający się. Cechuje się pojedynczymi, ciemnoróżowymi kwiatami oraz liśćmi złożonymi z dużej liczby drobnych listków. Kwitnie od maja, nie powtarzając kwitnienia (Wiśniewska-Grześkiewicz 2009).

Obserwacje prowadzono raz $\mathrm{w}$ tygodniu, w terminach od 16 czerwca do 3 sierpnia 2012 r. i od 28 czerwca do 19 sierpnia 2013 r. Z każdej odmiany pobierano losowo po 10 liści złożonych z górnej i dolnej części pędów. Łącznie zebrano 960 liści złożonych w roku 2012 i taką samą liczbę w roku 2013. Następnie próby przenoszone były do laboratorium, gdzie identyfikowano oraz liczono fitofagi. Obserwowano również objawy żerowania szkodników i określano stopień ich nasilenia. Łącznie zlustrowano 12172 pojedyncze liście (6546 w roku 2012 oraz 5626 w roku 2013).

\section{Wyniki i dyskusja / Results and discussion}

Na odmianie Frühlingsduft w roku 2013 obserwowano 2,53 osobników przędziorka chmielowca na liść, co stanowiło o połowę więcej niż w 2012 r. (1,65 os./liść). Przędziorek owocowiec występował na tej odmianie W roku 2013 siedmiokrotnie liczniej niż w roku po- 
przednim. Liczebność osobników tego gatunku wynosiła 0,13 os./liść w 2012 r. Liczba mszyc obserwowanych na tej odmianie była stosunkowo niewielka. W roku 2012 zanotowano jedynie 0,04 os./liść, natomiast w 2013 r. czterokrotnie mniej, czyli 0,01 os./liść. Mała liczebność mszyc mogła wynikać z obecności wrogów naturalnych tych szkodników, między innymi parazytoidów z rodzaju Aphidius. O ich występowaniu świadczyły znajdowane na liściach mumie mszyc. W 2012 i 2013 roku liczba mumii wynosiła po 0,04 os./liść (rys. 1). W roku 2012 odnotowano 0,07 liścia $\mathrm{z}$ uszkodzeniami skoczka różanego na próbę, natomiast w roku 2013 nieznacznie więcej, tj. 0,09 (rys. 7).

Na odmianie Nevada w roku 2013 odnotowano o ponad połowę mniej stadiów ruchomych przędziorka chmielowca (0,73 os./liść) niż w 2012 r. (1,58 os./liść). Mniejsza liczba tych fitofagów mogła wynikać $\mathrm{z}$ faktu, że na krzewie tym wykonywane było cięcie odmładzające. Poza tym odmiana ta, jak i Marguerite Hilling, w 2013 r. była silnie porażona przez grzyb Diplocarpon rosae powodujący czarną plamistość róż. Z obserwacji wynikało, że na liściach z silnymi objawami tej choroby występowało mniej przędziorków. Według Wojdyły i wsp. (2002) grzyb ten wytwarza metabolity głównie w postaci związków fenolowych i aminokwasów, które u szkodników powodują brak akceptacji lub antybiozę (Kiełkiewicz-Szaniawska 2003). Dodatkowo rośliny pod presją patogenów, w odpowiedzi na stres produkują więcej związków fenolowych, co może świadczyć o tym, że $T$. urticae unikał żerowania i przechodził na inne krzewy róż. Zjawisko spadku liczby przędziorków można też tłumaczyć konkurencją o miejsce żerowania między patogenem a szkodnikiem. W roku 2012 obserwowano pojedyncze osobniki przędziorka owocowca ( 0,01 os./liść). W następnym roku wystąpiło 7 razy więcej osobników $P$. ulmi (0,07 os./liść). Przez cały okres obserwacji liczebność tego fitofaga była niewielka. Liczba mszyc w roku 2013 była siedmiokrotnie większa niż w poprzednim ( 0,01 os./liść) i wynosiła 0,07 os./liść. Odwrotnie, liczba mumii była niższa w roku 2013 (0,05 os./liść) o połowę w stosunku do 2012 r. (0,1 os./liść) (rys. 2). Większa liczebność mszyc i mniej mumii w roku 2012 mogła wskazywać na występowanie mniejszej liczby parazytoidów tych szkodników. W 2012 r. nie znaleziono zbyt wielu liści z objawami żerowania skoczka różanego, tj. 0,02 liścia z objawami/próbę, natomiast w 2013 r. liczba uszkodzonych liści wzrosła do 0,03 (rys. 7).

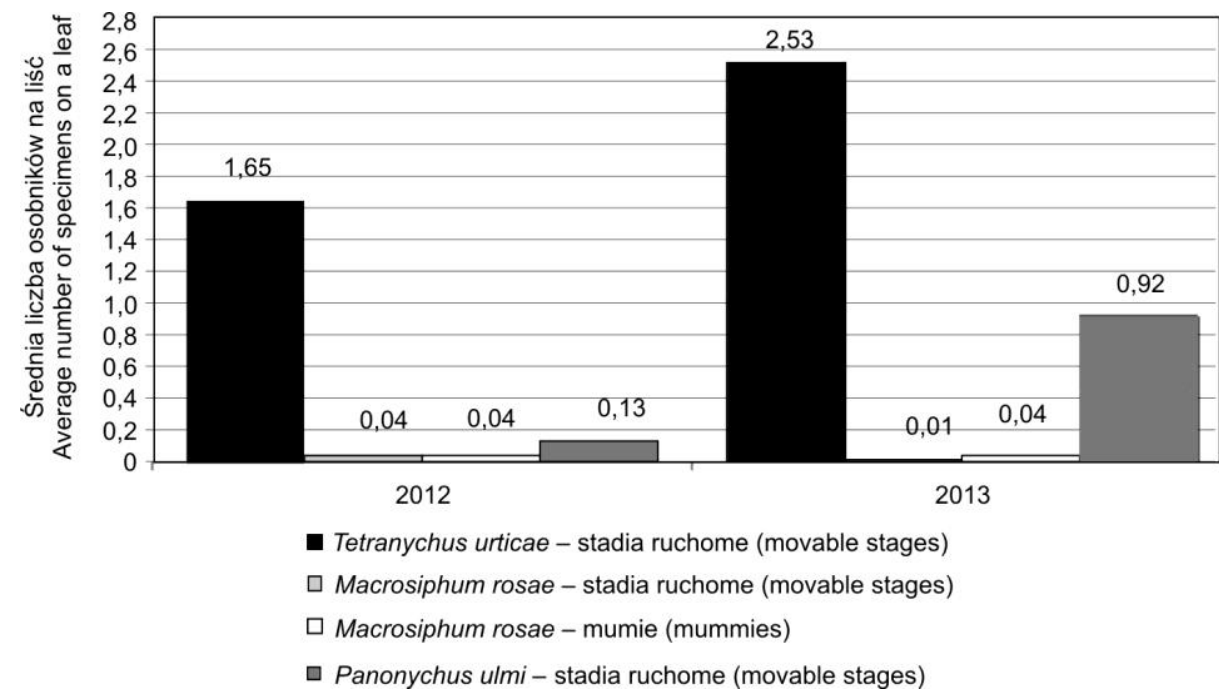

Rys. 1. Średnia liczba szkodników na liściach odmiany Frühlingsduft w latach 2012-2013

Fig. 1. Average number of pests on leaves variety Frühlingsduft in 2012-2013

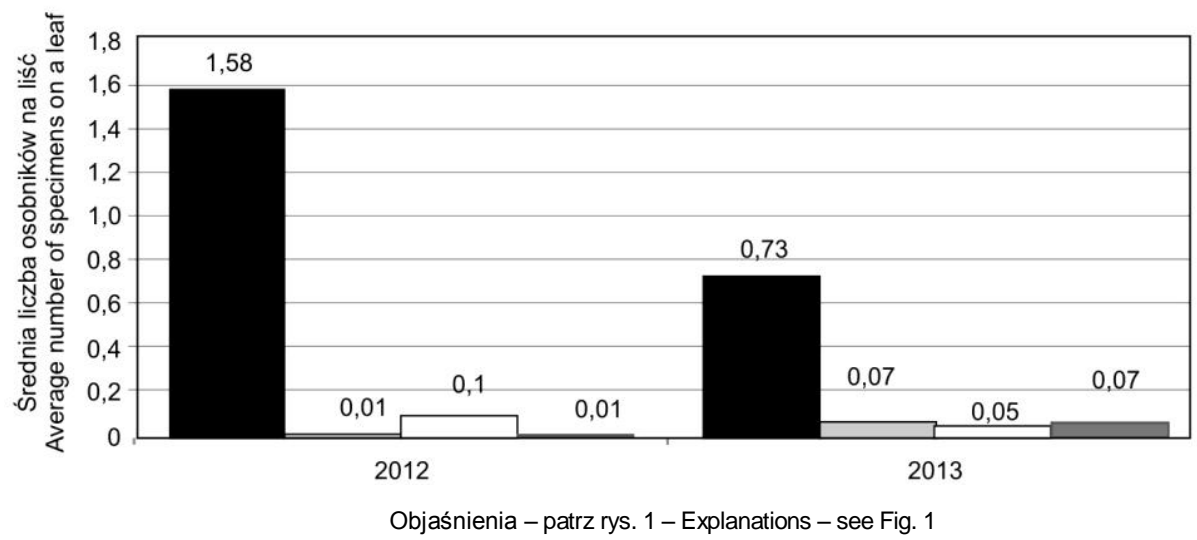

Rys. 2. Średnia liczba szkodników na liściach odmiany Nevada w latach 2012-2013

Fig. 2. Average number of pests on leaves variety Nevada in 2012-2013 


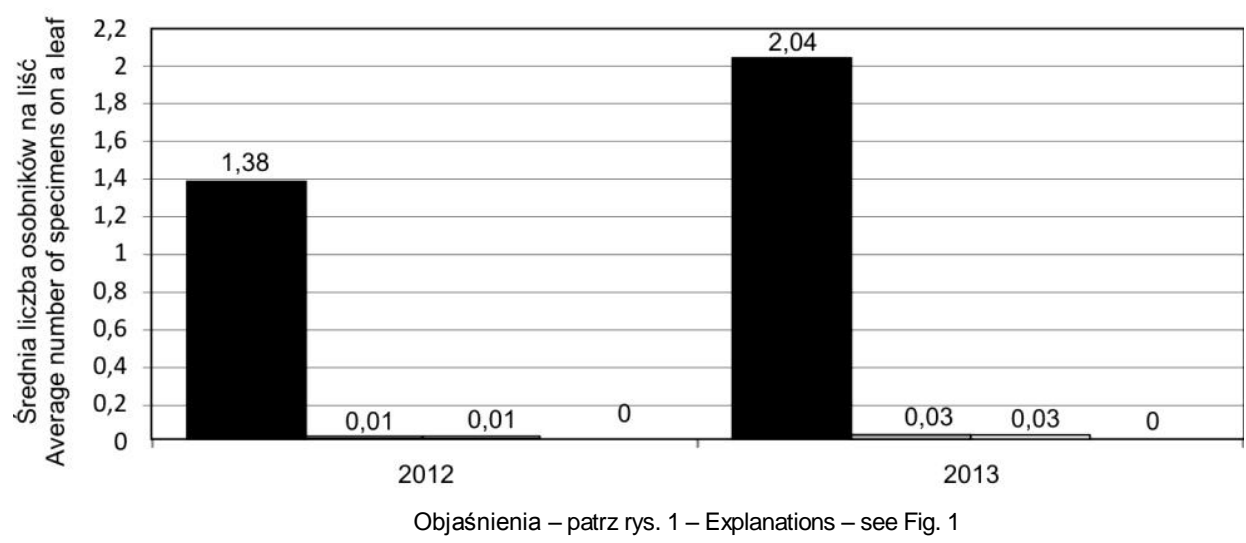

Rys. 3. Średnia liczba szkodników na liściach odmiany Harison's Yellow w latach 2012-2013

Fig. 3. Average number of pests on leaves variety Harison's Yellow in 2012-2013

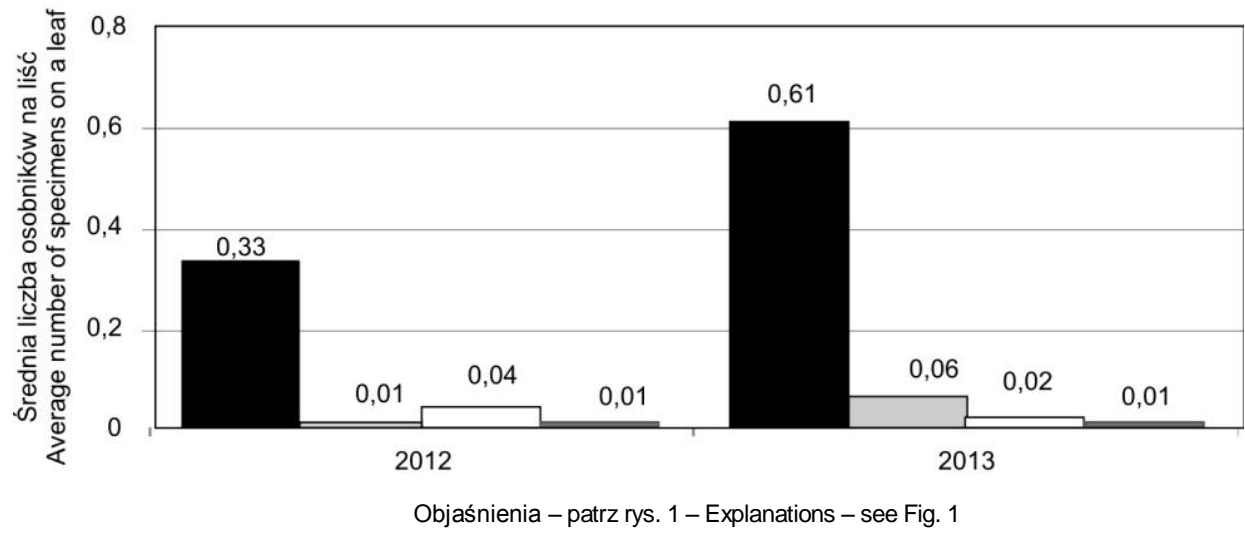

Rys. 4. Średnia liczba szkodników na liściach odmiany Poppius w latach 2012-2013

Fig. 4. Average number of pests on leaves variety Poppius in 2012-2013

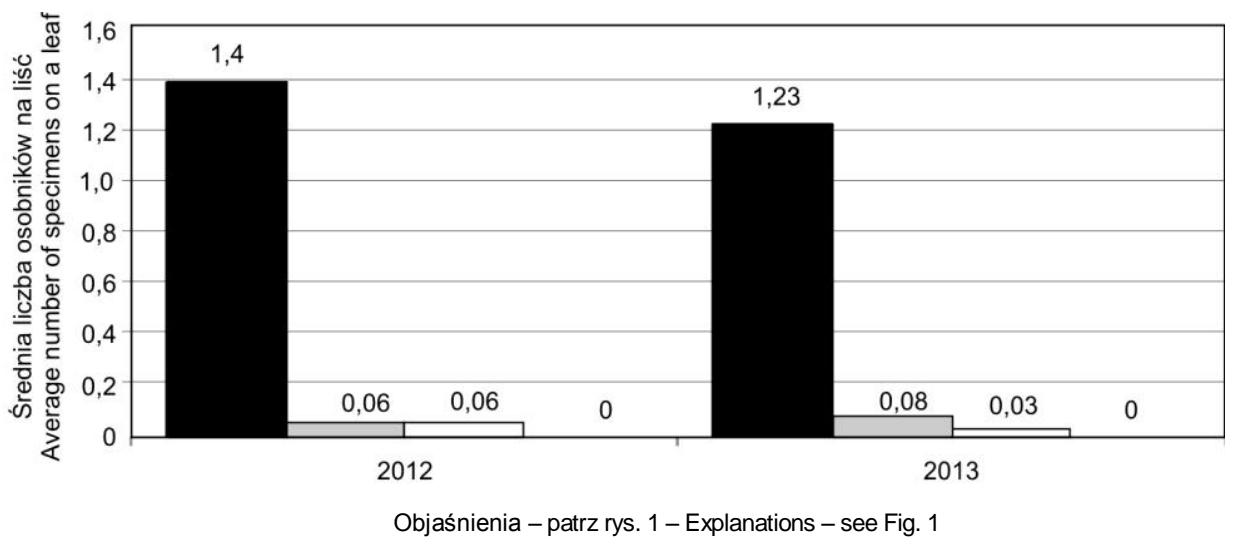

Rys. 5. Średnia liczba szkodników na liściach odmiany Marguerite Hilling w latach 2012-2013

Fig. 5. Average number of pests on leaves variety Marguerite Hilling in 2012-2013

$\mathrm{Na}$ odmianie Harison's Yellow obserwowano dość dużą liczebność T. urticae. W roku 2013 wynosiła 2,04 os./liść i była niemal o połowę większa niż w poprzednim roku (1,38 os./liść). Interesujący jest fakt, że zarówno na Harison's Yellow, jak i na Frühlingsduft, gdzie zaobserwowano najwięcej osobników przędziorka chmielowca, nie zauważono nasilonych objawów czarnej plamistości róż. Podobnie jak w przypadku odmiany Marguerite
Hilling, w czasie trwania obserwacji nie pojawiły się stadia ruchome $P$. ulmi, co może świadczyć, że odmiany te nie są preferowanymi roślinami żywicielskimi przez tego szkodnika lub są na niego odporne. W badaniach Lubiarz i Solskiego (2012) nie znaleziono żadnej $\mathrm{z}$ odmian niezasiedlanej przez $P$. ulmi. Szkodnik został zaobserwowany na $R$. rugosa, $R$. damascena oraz $R$. canina. W roku 2013 odnotowano 0,03 osobniki na liść mszycy różanej. Było to 


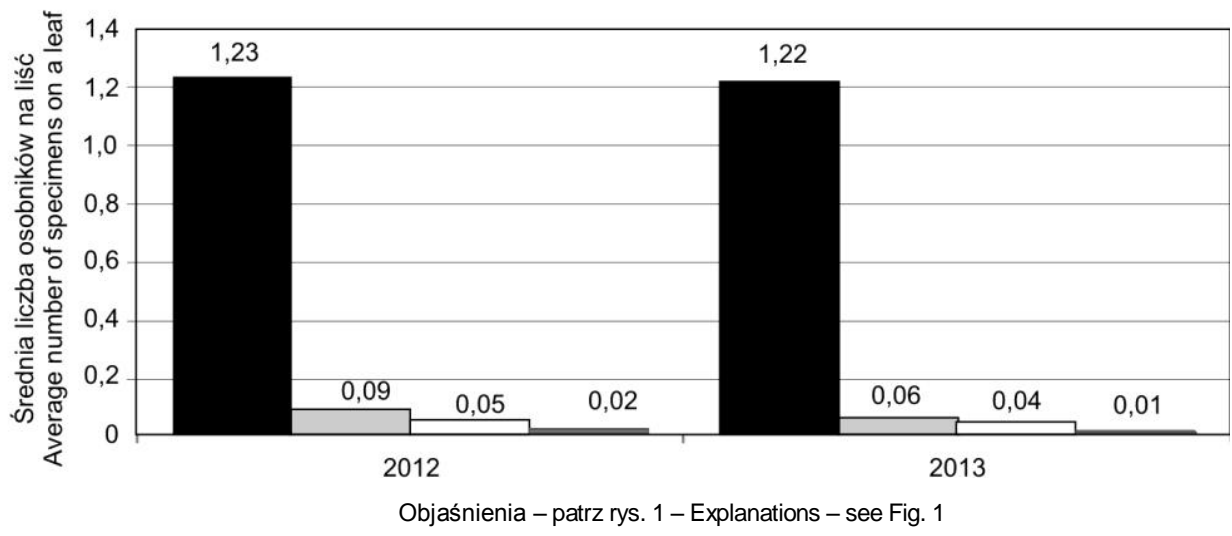

Rys. 6. Średnia liczba szkodników na liściach gatunku Rosa moyesii w latach 2012-2013

Fig. 6. Average number of pests on leaves species Rosa moyesii in 2012-2013

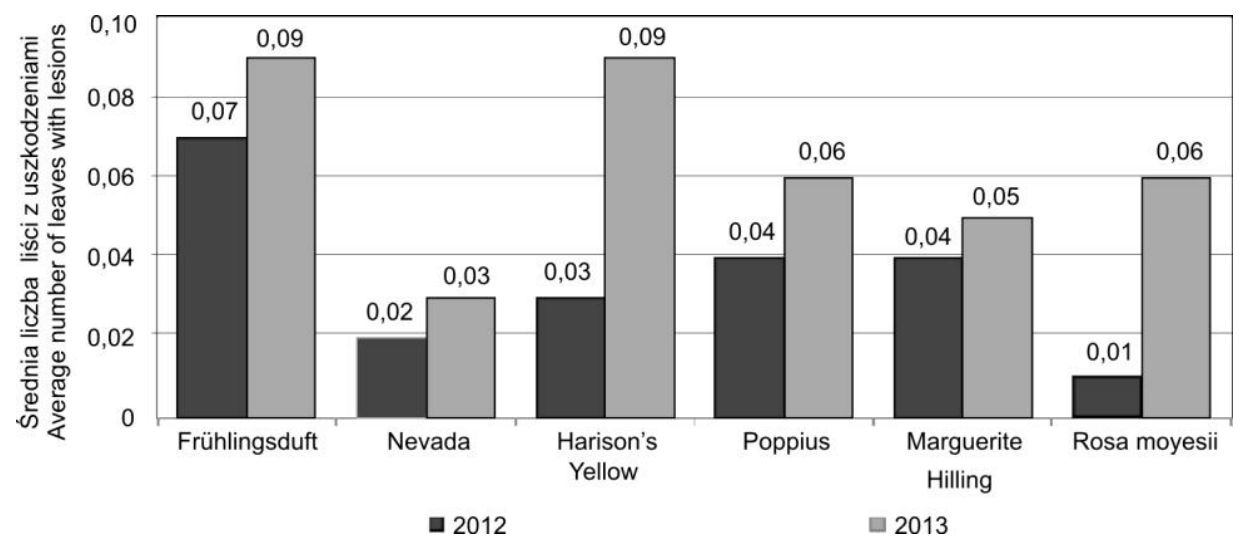

Rys. 7. Średnia liczba liści z uszkodzeniami Edwardsiana rosae w latach 2012-2013

Fig. 7. Average number of leaves with lesions Edwardsiana rosae in 2012-2013

3 razy więcej niż w roku poprzednim $(0,01$ os./liść). Trzykrotnie wzrosła również liczba osobników w porównaniu do 2012 r. (0,01 os./liść) (rys. 3). W roku 2013 obserwowano też trzykrotnie więcej liści z uszkodzeniami powodowanymi przez $E$. rosae $(0,09$ liści $\mathrm{z}$ objawa$\mathrm{mi} /$ próbę) w stosunku do 2012 r. (0,03 liści z objawami/próbę) (rys. 7).

Odnotowano stosunkowo niewielką liczebność przędziorka chmielowca na odmianie Poppius. W roku 2012 wynosiła jedynie 0,33 os./liść, a w 2013 r. wzrosła prawie dwukrotnie do 0,61 os./liść. Na tej odmianie zauważono również pojedyncze osobniki przędziorka owocowca. W trakcie dwuletnich badań ich liczba wynosiła jedynie 0,01 os./liść. W drugim roku obserwacji znacznie, bo aż sześciokrotnie, wzrosła liczebność mszycy różanej W stosunku do 2012 roku, gdy obserwowano 0,01 os./liść. Liczba mumii była dwukrotnie mniejsza w roku 2013 (0,02 os./liść) w stosunku do roku 2012 (0,04 os./liść) (rys. 4). Sytuacja ta może wynikać z mniejszej liczby parazytoidów mszyc w roku 2013. Liczba liści z objawami żerowania skoczka różanego wynosiła w 2012 roku 0,4 liścia z objawami/próbę, a w 2013 r. o połowę więcej, tj. 0,6 (rys. 7).

W przypadku odmiany Marguerite Hilling na przestrzeni 2 lat obserwowano jedynie niewielkie zmiany w liczebności przędziorków. W roku 2012 zanotowano
1,4 os./liść przędziorka chmielowca, natomiast w kolejnym roku na liściach pojawiło się mniej stadiów ruchomych tego fitofaga (1,23 os./liść). W trakcie trwania obserwacji nie odnotowano żadnych stadiów ruchomych przędziorka owocowca. W przypadku mszycy M. rosae w roku 2013 znaleziono więcej, bo 0,08 os./liść, w stosunku do 2012 roku (0,06 os./liść). Zanotowano również o połowę mniej mumii w roku $2013(0,03$ os./liść $)$ w porównaniu do poprzedniego roku (0,06 os./liść) (rys. 5). Tak jak w przypadku wcześniej wymienianych odmian, większa liczba mszyc obserwowana w 2013 roku w stosunku do mumii może świadczyć o zmniejszeniu liczby parazytoidów tych szkodników. W 2012 roku zebrano 0,04 liścia z uszkodzeniami powodowanymi przez E. rosae, natomiast w 2013 r. 0,05 liścia $\mathrm{z}$ objawami/próbę (rys. 7).

Na gatunku $R$. moyesii zanotowano nieznaczne zmiany w liczebności $T$. urticae na przestrzeni dwóch lat. W roku 2012 liczebność tego szkodnika wynosiła 1,23 os./liść, w następnym roku była zbliżona (1,22 os./liść). W 2013 r. obserwowano pojedyncze osobniki przędziorka owocowca (0,01 os./liść). Było to dwukrotnie mniej niż w poprzednim roku, gdy liczebność $P$. ulmi wynosiła 0,02 os./liść. W 2012 r. na $R$. moyesii zanotowano 0,09 osobnika mszycy różanej na liść. W następnym roku było ich o $1 / 3$ mniej, czyli 0,06 os./liść. Nieznacznie spadła liczba mumii, z 0,05 os./liść w roku 2012 do 0,04 os./liść w 2013 r. 
(rys. 6). W roku 2013 zebrano dziewięciokrotnie więcej liści z objawami występowania skoczka różanego $(0,09$ liścia $\mathrm{z}$ objawami/próbę) niż $\mathrm{w}$ roku 2012, tj. 0,01 liścia z objawami/próbę (rys. 7).

W roku 2012 najwięcej stadiów ruchomych przędziorka chmielowca obserwowano na $R$. moyesii (1667 osobników) oraz Frühlingsduft (1577). W kolejnym roku najchętniej atakowaną przez tego szkodnika odmianą była ponownie Frühlingsduft. Zanotowano na niej 1891 osobników. Dużo przędziorka wystąpiło również na liściach Harison's Yellow (1775). Najmniej osobników T. urticae znaleziono zarówno w roku 2012 i 2013 na odmianie Poppius, kolejno 425 i 654 osobniki. W 2013 roku mało przedstawicieli gatunku $T$. urtice odnotowano na odmianie Nevada - 667 sztuk. W przypadku przędziorka owocowca na odmianach Harison's Yellow i Marguerite Hilling szkodnik ten nie pojawił się w czasie prowadzonych obserwacji. Pojedyncze osobniki $P$. ulmi występowały na odmianie Poppius. W latach 2012-2013 zaobserwowano odpowiednio 3 i 15 osobników. W przypadku $R$. moyesii $\mathrm{W}$ 2012 r. odnotowano 24 osobniki, a w kolejnym 13. Najwięcej stadiów ruchomych $P$. ulmi obserwowano w 2013 roku na Frühlingsduft, bo aż 685 sztuk. Drugą preferowaną przez szkodnika odmianą okazała się Nevada. W 2013 roku znaleziono 66 osobników przędziorka owocowca, gdzie rok wcześniej zanotowano jedynie 2 . Pojawianie się pojedynczych osobników tego fitofaga na niektórych krzewach świadczy o tym, że mógł swobodnie przenosić się między roślinami. W związku z tym można przypuszczać, że odmiany, na których znajdowało się najwięcej osobników tego gatunku są przez niego preferowane. Łącznie największą liczbę przędziorków w trakcie dwuletnich badań zanotowano na róży Frühlingsduft, natomiast najmniejszą na odmianie Poppius (tab. 1).
W 2012 roku zdecydowanie najwięcej mszycy różanej obserwowano na $R$. moyesii (121 osobników). W dużej liczebności występowały też na Marguerite Hilling (64). Pojedyncze osobniki obserwowano na krzewach Nevada (9) i Harison's Yellow (5). Interesujący jest fakt, że najwięcej mumii $w$ tym roku znaleziono na odmianie Nevada (91). W roku 2013 większość krzewów była podobnie zasiedlana przez mszyce. Na Marguerite Hilling stwierdzono 70 osobników, na Poppius 69, na Nevada i $R$. moyesii po 67. Zaobserwowano, że na Frühlingsduft, gdzie występowało najwięcej przędziorków, znaleziono jedynie 6 mszyc. Najwięcej mumii zanotowano na $R$. moyesii (51) oraz Nevada (48), co świadczy o licznym występowaniu parazytoidów mszyc. Łączna liczba mszyc w roku 2013 była większa niż w 2012. Natomiast liczba mumii spadła o 1/3 w stosunku do roku 2013. Może to oznaczać, że w 2013 r. pojawiło się znacznie mniej parazytoidów mszyc. Najwięcej liści z uszkodzeniami spowodowanymi przez skoczka różanego obserwowano w 2012 r. na odmianie Frühlingsduft (71), natomiast w 2013 r. na Harison's Yellow (80) (tab. 2).

W ciągu dwóch lat na wszystkich badanych krzewach róż znalezione zostały mumie mszyc. Podobne wyniki uzyskali na $R$. rugosa, $R$. damascena oraz $R$. canina Lubiarz i Solski (2012). Dodatkowo przeprowadzili badania dotyczące występowania osobników z podrodziny Aphidiinae. Na gatunku $R$. rugosa przedstawiciele tej grupy stanowili $36 \%$ wszystkich pożytecznych owadów, kolejno na $R$. damascena $30 \%$ oraz $12 \%$ na $R$. canina. Duża liczba charakterystycznych mumii w zebranych próbach w Powsinie może być wynikiem występowania licznej populacji przedstawicieli parazytoidów z Aphidiinae.

Tabela 1. Występowanie przędziorków na liściach róż

Table 1. The occurrence of mites on the leaves of roses

\begin{tabular}{|c|c|c|c|c|}
\hline $\begin{array}{l}\text { Odmiana/gatunek } \\
\text { Cultivar/species }\end{array}$ & $\begin{array}{l}\text { Rok obserwacji } \\
\text { Year of observation }\end{array}$ & $\begin{array}{l}\text { Tetranychus urticae - stadia } \\
\text { ruchome [liczba osobników] } \\
\text { Tetranychus urticae - movable } \\
\text { stages [number of specimens] }\end{array}$ & $\begin{array}{c}\text { Panonychus ulmi - stadia } \\
\text { ruchome [liczba osobników] } \\
\text { Panonychus ulmi - movable } \\
\text { stages [number of specimens] }\end{array}$ & $\begin{array}{c}\text { Razem } \\
\text { Total }\end{array}$ \\
\hline \multirow{2}{*}{ Frühlingsduft } & 2012 & 1577 & 127 & 1704 \\
\hline & 2013 & 1891 & 685 & 2576 \\
\hline \multirow{2}{*}{ Nevada } & 2012 & 1508 & 2 & 1510 \\
\hline & 2013 & 667 & 66 & 733 \\
\hline \multirow{2}{*}{ Harison's Yellow } & 2012 & 1335 & 0 & 1335 \\
\hline & 2013 & 1775 & 0 & 1775 \\
\hline \multirow{2}{*}{ Poppius } & 2012 & 425 & 3 & 428 \\
\hline & 2013 & 654 & 15 & 669 \\
\hline \multirow{2}{*}{ Marguerite Hilling } & 2012 & 1431 & 0 & 1431 \\
\hline & 2013 & 1104 & 0 & 1104 \\
\hline \multirow{2}{*}{ Rosa moyesii } & 2012 & 1667 & 24 & 1691 \\
\hline & 2013 & 1386 & 13 & 1399 \\
\hline \multirow{2}{*}{$\begin{array}{l}\text { Razem } \\
\text { Total }\end{array}$} & 2012 & 7943 & 156 & 8099 \\
\hline & 2013 & 7477 & 779 & 8256 \\
\hline
\end{tabular}


Tabela 2. Występowanie mszycy Macrosiphum rosae i mumii na liściach róż oraz liści z objawami żerowania skoczka różanego

Table 2. The occurrence of aphid Macrosiphum rosae and aphid mummies on the leaves of roses and leaves with symptoms of rose leafhopper feeding

\begin{tabular}{|c|c|c|c|c|}
\hline $\begin{array}{l}\text { Odmiana/gatunek } \\
\text { Cultivar/species }\end{array}$ & $\begin{array}{c}\text { Rok obserwacji } \\
\text { Year } \\
\text { of observation }\end{array}$ & $\begin{array}{l}\text { Macrosiphum rosae - stadia } \\
\text { ruchome [liczba osobników] } \\
\text { Macrosiphum rosae - movable } \\
\text { stages [number of specimens] }\end{array}$ & $\begin{array}{c}\text { Macrosiphum rosae - mumie } \\
\text { [liczba osobników] } \\
\text { Macrosiphum rosae - mummies } \\
\text { [number of specimens] }\end{array}$ & $\begin{array}{c}\text { Edwardsiana rosae } \\
\text { - liczba liści } \\
\text { z uszkodzeniami } \\
\text { Edwardsiana rosae - } \\
\text { number of leaves } \\
\text { with lesions }\end{array}$ \\
\hline Frühlingsduft & 2012 & 32 & 40 & 71 \\
\hline \multirow{2}{*}{ Nevada } & 2012 & 9 & 91 & 16 \\
\hline & 2013 & 67 & 48 & 29 \\
\hline \multirow{2}{*}{ Harison's Yellow } & 2012 & 5 & 12 & 27 \\
\hline & 2013 & 24 & 28 & 80 \\
\hline Poppius & 2012 & 15 & 45 & 49 \\
\hline \multirow{2}{*}{ Marguerite Hilling } & 2012 & 64 & 65 & 37 \\
\hline & 2013 & 70 & 26 & 43 \\
\hline \multirow{2}{*}{ Rosa moyesii } & 2012 & 121 & 69 & 11 \\
\hline & 2013 & 67 & 51 & 67 \\
\hline \multirow{2}{*}{$\begin{array}{l}\text { Razem } \\
\text { Total }\end{array}$} & 2012 & 246 & 322 & 211 \\
\hline & 2013 & 303 & 199 & 329 \\
\hline
\end{tabular}

Biorąc pod uwagę ogólną liczbę wszystkich fitofagów, w roku 2013 stwierdzono wzrost ich liczby w stosunku do 2012 r., co może być spowodowane warunkami atmosferycznymi. Według obserwacji autorów niniejszej publikacji w 2013 roku w rejonie Warszawy lato było bardzo ciepłe i suche w porównaniu do poprzedniego sezonu wegetacyjnego, gdzie temperatury były niższe, a opady znacznie częstsze i obfitsze. Najlepszą z badanych odmian do nasadzeń amatorskich oraz parkowych, w których ograniczona jest możliwość wykonania zabiegów chemicznych, okazała się odmiana Poppius. Natomiast popularna Frühlingsduft, mimo długiego okresu kwitnienia, atrakcyjnej barwy kwiatów oraz przyjemnego zapachu (Wiśniewska-Grzeszkiewicz 2009), jest najchętniej zasiedlana przez szkodniki. Wybór tej odmiany do nasadzeń amatorskich i parkowych może stać się przyczyną nagromadzenia i rozprzestrzenienia żerujących na niej polifagów $\mathrm{z}$ rodziny przędziorkowatych na inne sąsiadujące krzewy i rośliny.

\section{Wnioski / Conclusions}

1. Odmiana Poppius była najmniej podatna na szkodniki takie, jak: mszyca różana ( $M$. rosae), przędziorki (T. urticae, $P$. ulmi) i skoczka różanego (E. rosae).

2. Odmiana Frühlingsduft była najchętniej atakowana przez szkodniki spośród badanych odmian i form dzikich róż.

3. Harison's Yellow oraz $R$. moyesii były w podobnym stopniu zasiedlane przez przędziorka chmielowca, co świadczy o tym, że szkodnik preferuje zarówno odmianę Harison's Yellow, jak i formę dziką R. moyesii.

4. Wraz $\mathrm{z}$ nasileniem występowania objawów czarnej plamistości róży na odmianach Nevada i Marguerite Hilling zmalała liczba osobników przędziorka chmielowca.

\section{Literatura / References}

Budha P.B., Thapa V.K. 2008. Infestation pattern of Macrosiphum rosae and Tetranychus sp. in rose plants (Rosa hybrida) cultivated in protected and open cultivation in Kathmandu district. Journal of Natural History Museum 23: 88-91.

Chakrabarti S. 2005. Diversity of aphid (Insecta: Homoptera) fauna their host plant diversity in Western and Northwest Himalaya. p. 23-38. In: "Biodiversity and Natural Heritage of the Himalaya II" (M. Hartmann, J. Wipert, eds.). Naturkundemuseums Erfurt, Germany, $534 \mathrm{pp}$.

Davoodi Z. 1980. Some morphological and bio-ecological studies on Edwardsiana rosae L. Entomologie et Phytopathologie Appliquees 48 (1): 53-65.

Dhooria M.S. 1999. Two spotted spider mite. Tetranychus urticae, a serious pest of roses in polyhouses and its control. Journal of Acarology 14: 84-87. 
Ferran A., Niknam H., Kabiri F., Picard J., de Herce C., Brun J., Iperti G., Lapchin L. 1996. The use of Harmonia axyridis larvae (Coleoptera: Coccinellidae) against Macrosiphum rosae (Hemiptera: Stenorrhyncha: Aphididae) on rose bushes. European Journal of Enthomology 93: 59-67.

Jankowska B. 2005. Predatory syrphids (Diptera, Syrphidae) occuring in the cabbage aphid (Brevicoryne brassicae L.) collonies on the different cabbage vegetables. Journal of Plant Protection Research 45 (1): 9-16.

Jaśkiewicz B., Sławińska A. 2005. The complex of parasitic Hymenoptera (Hymenoptera: Parasitica) occuring in aphids colonies on decorative shrubs in the urban environment. Annales Universitatis Mariae Curie-Skłodowska XV, Sectio EEE: 127-135.

Kiełkiewicz-Szaniawska M. 2003. Strategie obronne roślin pomidorów (Lycopersicon esculentum Miller) wobec przędziorka szklarniowca (Tetranychus cinnabarinus Boisduval, Acari: Tetranychidae). Rozprawy Naukowe, SGGW, Warszawa, 140 ss.

Kmieć K. 2007. Constancy of occurence of aphid community (Hemiptera, Aphididae) on the roses in the urban conditions of Lublin. Annales Universitatis Mariae Curie-Skłodowska XVII (1), Sectio EEE: 53-59.

Kumar K.S.D., Nandihalli B.S. 2009. Evaluation of botanicals and mycopathogens in the management of mites and thrips under polyhouse condition. Karnataka Journal of Agricultural Sciences 22 (3): 696-697.

Lubiarz M., Solski M. 2012. Arthropods on rose bushes in the Botanical Garden of UMCS (Maria Curie-Skłodowska University) in Lublin (South-Eastern Poland). Aphids and Other Hemipterous Insects 18: 57-69.

Maelzer D.A. 1977. The biology and main causes of changes in numbers of the rose aphid, Macrosiphum rosae (L.), on cultivated roses in South Australia. Australian Journal of Zoology 25 (2): 269-284.

Markkula M., Tiitanen K., Hamalainen M., Forsberg A. 1979. The aphid midge Aphidoletes aphidimyza (Diptera, Cecidomyiidae) and its use in biological control of aphids. Annales Entomologici Fennici 45 (4): 89-98.

McCaffery A.R., King A.B.S., Walker A.J., Nayir H. 1989. Resistance to synthetic pyrethroids in Heliotis armigera Andhra Pradesh. India. Pesticide Science 27 (1): 65-76.

Tomiuk J., Wöhrmann K. 1984. Genotypic variability in natural populations of Macrosiphum rosae (L.) in Europe. Biologisches Zentralblatt 103 (2): 113-122.

Wiśniewska-Grzeszkiewicz H. 2009. Róże w ogrodzie. Ogrodnik doskonały, Multico, Warszawa, 168 ss.

Wnuk A. 2004. Occurence of aphidophagous syrphid (Diptera, Syrphidae) in colonies of Macrosiphum rosae L. on roses in Botanical Garden of the Jagiellonian University Cracov. Protection of Plant Collection against Pests and Diseases 2: 44-48.

Wnuk A. 2005. Roślinność w łańcuchach pokarmowych dla mszycożernych bzygowatych (Diptera, Syrphidae). s. 95-104. W: „Ochrona środowiska naturalnego w XXI wieku - nowe wyzwania i zagrożenia”. Fundacja na Rzecz Wspierania Badań Naukowych Wydziału Ogrodniczego w Krakowie, 136 ss.

Wojdyła A., Kamińska M., Łabanowski G., Orlikowski L. 2002. Ochrona róż. Plantpress, Kraków, 112 ss. 